\title{
Influence of fungicide and sowing density on the growth and yield of two groundnut cultivars
}

\author{
J. B. NAAB ${ }^{1}$, K. J. BOOTE ${ }^{2}$, P. V. V. PRASAD ${ }^{3 *}$, S. S. SEINI ${ }^{1}$ AND J. W. JONES ${ }^{4}$ \\ ${ }^{1}$ Savanna Agricultural Research Institute, Wa Experiment Station, POB 494, Wa, Ghana \\ ${ }^{2}$ Agronomy Department, University of Florida, Gainesville, FL 32611, USA \\ ${ }^{3}$ Agronomy Department, Kansas State University, Manhattan, KS 66506, USA \\ ${ }^{4}$ Agricultural and Biological Engineering, University of Florida, Gainesville, FL 32611, USA
}

(Revised MS received 24 September 2007; First published online 24 December 2008)

\begin{abstract}
SUMMARY
Groundnut or peanut (Arachis hypogaea L.) is a valuable food and forage crop in West Africa. It is important to determine yield-limiting factors and to develop suitable management practices to improve groundnut productivity. The objective of the present research was to determine the influence of fungicide application at different sowing densities on growth, biomass and yield of early and late maturing groundnut under rainfed conditions. Two groundnut cultivars (Chinese, 90 days duration and Manipinter, 120 days duration) were grown at low $\left(8 \mathrm{plants} / \mathrm{m}^{2}\right)$, medium $\left(12 \mathrm{plants} / \mathrm{m}^{2}\right)$ and high density (20 plants $\left./ \mathrm{m}^{2}\right)$, with and without fungicide application, for two growing seasons (2004 and 2005). Data on leaf area index (LAI), light interception (LI) and total biomass were measured at different stages of crop development. Haulm (stem and leaf), pod and seed yields were measured at maturity. Fungicide application increased LAI, LI and total biomass of both cultivars from 65 days after sowing (DAS) until maturity. Fungicide application significantly increased pod and seed yields by 95 and $103 \%$, respectively, on average. In both years, the long duration cultivar Manipinter had significantly greater LAI, LI and total biomass at later stages of crop development when compared with the short-duration cultivar Chinese. The growth and yield of both cultivars were significantly less at the lowest population density when compared with medium or high population densities. There was no significant difference between medium and high population densities in haulm, pod and seed yield at maturity. It is concluded that sowing a long-duration cultivar at a density of 12 plants $/ \mathrm{m}^{2}$ with fungicide application significantly improved groundnut yields under rainfed conditions in Ghana.
\end{abstract}

\section{INTRODUCTION}

Groundnut (peanut) is an important cash crop in Ghana due to its high protein $(0 \cdot 25-0 \cdot 30)$ and edible oil $(0 \cdot 48-0 \cdot 50)$ content, compared with other oilseed crops in that region. The average yields of groundnut in Ghana are lower $(903 \mathrm{~kg} / \mathrm{ha})$ than those in South Africa $(2000 \mathrm{~kg} / \mathrm{ha})$, Asia $(1798 \mathrm{~kg} / \mathrm{ha})$ or the rest of the world (1447 kg/ha) (FAO 2005). The lower yields in Ghana are mainly attributed to leaf spot diseases and $\mathrm{P}$ deficiency (Naab et al. 2005). Early leafspot (Cercospora arachidicola S. Hori) and late leafspot (Cercosporidium personatum (Ber. \& Curtis) Deighton)

* To whom all correspondence should be addressed. Email: vara@ksu.edu are critical yield-limiting diseases of groundnut in Ghana and West Africa (Waliyar 1991; Waliyar et al. 2000 ), accounting for yield reductions of $50-70 \%$ where fungicides are not used (Waliyar 1991; Shokes \& Culbreath 1997). Although some recent studies have documented leafspot-tolerant cultivars (Stalker et al. 2002; Singh et al. 2003), these cultivars are not readily available to the farmers of this region. Furthermore, induction of leafspot resistance into commercial cultivars available for use by farmers will take years. In addition, the tolerance in these cultivars may not be adequate under the high disease pressures of this region. Thus, the most important tool presently available for controlling these diseases is the use of fungicides. Previous studies by the present authors have shown significant yield improvement 
(up to $75 \%$ ) with fungicide application under experiment station conditions (Naab et al. 2005). However, most of the fungicide response work has been done under the sowing density recommended for no fungicide situations. Little research has been done to document the effects of sowing density in conjunction with fungicide use on the development of leafspot disease and final yield.

Crop management practices such as date of sowing, sowing density and duration of cultivar life cycle will influence environment during the crop growth period, which in turn can affect the severity of leafspot and growth and yield of groundnut (Cox \& Reid 1965; Farrel et al. 1967; Chin-Choy et al. 1982). Thus, it is important to determine the differences in yield due to diseases under various crop management practices. Among cultural practices, many authors have emphasized the importance of plant density (Mligo \& Craufurd 2007), cultivar selection (Banterng et al. 2003), planting date (Naab et al. 2005) and fungicide application (Dimmock \& Gooding 2002; Russell 2005) and their integration (Marley 2004; Naab et al. 2005). Altering plant population can affect crop yield, quality factors and pest development in groundnut (Kumar \& Venkatachari 1971; Lanier et al. 2004). Groundnut yield was often higher in standard twin row planting patterns (two rows spaced $0.18 \mathrm{~m}$ apart on $0.91 \mathrm{~m}$ centres) compared with single row planting (rows spaced on $0.91 \mathrm{~m}$ centres) patterns (Lanier et al. 2004). The severity of tomato spotted wilt virus differed among planting patterns, with lower severity observed on standard twin row planting compared with single row planting patterns (Lanier et al. 2004). Roy et al. (1980) recorded optimum pod yield with plant density ranging from 18 to 30 plants $/ \mathrm{m}^{2}$. Mercer-Quarshie (1972) recorded maximum yield using plant densities of 22 and 33 plants $/ \mathrm{m}^{2}$. Increasing plant density has often been shown to increase total dry matter production and numbers of reproductive components per unit land area in groundnut, but the yield response of the economically important components (e.g. mature pods and kernels) is more variable (Bell et al. 1991). Wright \& Bell (1992) reported that reproductive development was strongly influenced by plant population density, with more pods $/ \mathrm{m}^{2}$ in low $\left(4\right.$ plants $\left./ \mathrm{m}^{2}\right)$ than high (12 or 24 plants $/ \mathrm{m}^{2}$ ) sowing density. In contrast, Mayeux \& Maphanyane (1989) reported that yields of a Spanish variety were highest at a density of 16.6 plants $/ \mathrm{m}^{2}$ and lowest at 3.7 plants $/ \mathrm{m}^{2}$. Very low density led to prolonged flowering, uneven maturity and low shelling proportion. In Ghana the current recommendation is a $0.5 \mathrm{~m}$ row spacing with $0.1 \mathrm{~m}$ spacing in the row $\left(20\right.$ plants $\left./ \mathrm{m}^{2}\right)$, but the majority of farmers are unable to sow at the recommended within-row spacing because it requires more seed, which is expensive and is also labour intensive. Typical plant populations in farmers' fields range from 5 to 8 plants $/ \mathrm{m}^{2}$.
Determining interactions of fungicides with variables such as cultivar selection and sowing density will help develop efficient production and pest management options for groundnut. The present authors hypothesize that lower sowing densities may be feasible with longer season cultivars when combined with the use of fungicide for obtaining greater yields. The objective of the present research was to evaluate the effects of fungicide and sowing density on the growth and yield of early and late maturing groundnut cultivars grown under rainfed conditions.

\section{MATERIALS AND METHODS}

Field research was conducted during the 2004 and 2005 growing seasons at the Savanna Agricultural Research Institute farm at Wa (latitude $9 \cdot 0^{\circ} \mathrm{N}$, longitude $2 \cdot 0^{\circ} \mathrm{W}, 390 \mathrm{~m}$ asl). The soil at the experimental site was a sandy loam with $\mathrm{pH}$ of $6 \cdot 3$, organic matter content of $4.9 \mathrm{~g} / \mathrm{kg}$, total $\mathrm{N}$ of $0.6 \mathrm{~g} \mathrm{~N} / \mathrm{kg}$ and available Bray-1 P of $15 \cdot 1 \mathrm{mg} / \mathrm{kg}$ soil in the top $0.45 \mathrm{~m}$ of soil. Daily rainfall, maximum and minimum temperatures (Fig. 1) and sunshine hours were recorded by an automatic HOBO weather station (Onset Corporation, Pocasset, MA, USA) located at the experimental site.

\section{Treatments and crop husbandry}

Two groundnut cultivars, Chinese (90 days duration) and Manipinter (120 days duration), were sown at three densities, 8 (low), 12 (medium) and 20 (high) plants $/ \mathrm{m}^{2}$, with $(+\mathrm{F})$ and without $(-\mathrm{F})$ fungicide application. The experimental design was a randomized complete block in a split-split arrangement with four replications. Main plot treatments were fungicide levels, sub-plot treatments were cultivars and sub-sub-plot treatments were sowing densities. Main plot size was $16 \times 12 \mathrm{~m}$, sub-plot size was $8 \times 12 \mathrm{~m}$ and sub-sub-plot size was $8 \times 4 \mathrm{~m}$ (eight rows).

Each year before sowing, the field was disc ploughed and harrowed. Following field preparation, single super phosphate fertilizer $\left(0 \cdot 16 \mathrm{P}_{2} \mathrm{O}_{5}\right)$ was applied to the seedbed at a rate of $60 \mathrm{~kg} \mathrm{P}_{2} \mathrm{O}_{5} /$ ha and incorporated into the soil using hoes. Seeds were sown on a flatbed in rows at a spacing of $0.50 \mathrm{~m}$ and intra-row spacing of 0.25 (low density), $0 \cdot 16$ (medium density) or $0.10 \mathrm{~m}$ (high density) depending on the sowing density. Sowings were done on 19 June 2004 and 23 June 2005. In the fungicide-treated plots, Folicur (Tebuconazole, Bayer Crop Science) at $0 \cdot 22 \mathrm{~kg}$ a.i./ha was sprayed beginning 21 days after sowing (DAS) and at 14-day intervals until harvest. There were a total of four sprays during the growing season. Fungicide was sprayed using a back-mounted 15-litre knapsack sprayer with a spray volume of 150 litres/ha. Weeds were controlled manually, using hoes, when necessary. 


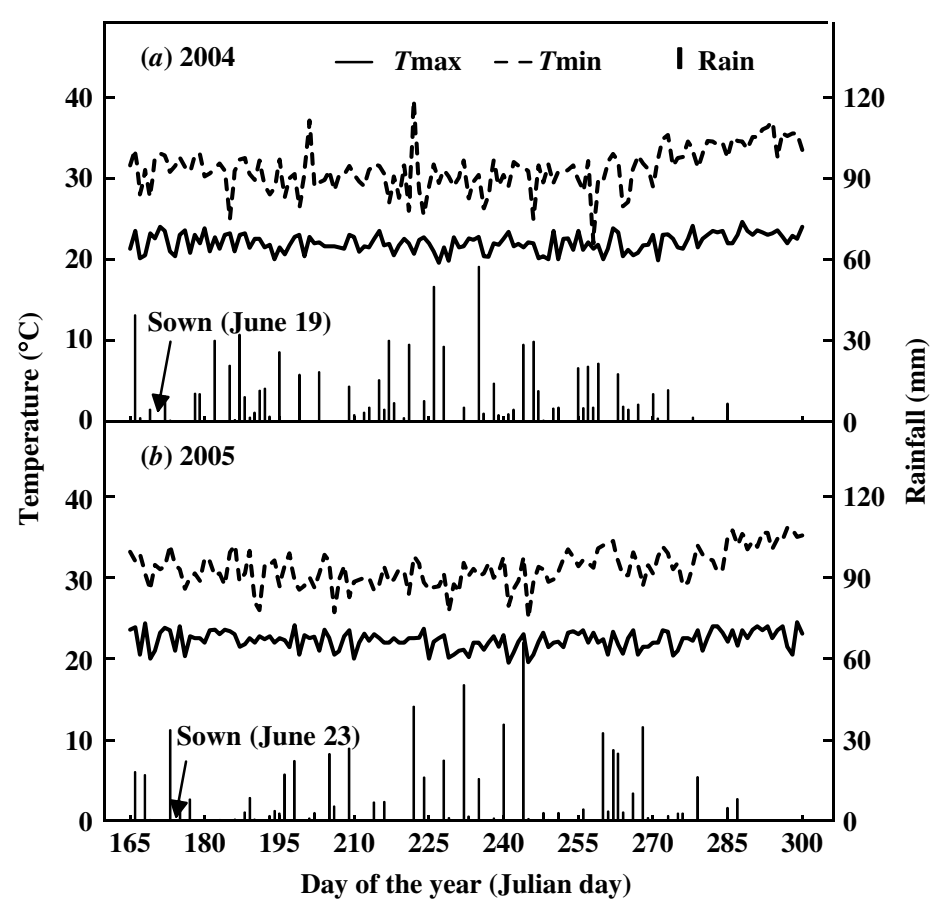

Fig. 1. Mean daily minimum and maximum temperatures and rainfall during the experimental period in $2004(a)$ and $2005(b)$ growing seasons.

\section{Plant measurements}

Leaf area index (LAI) and light interception (LI) were measured at 65, 77 and 88 DAS in 2004 and at 63, 74, $83,90,98$ and 120 DAS in 2005 by taking the average of six parallel (Board \& Harville 1992) measurements per plot, three along the base of the row and three in the middle of the row. All LAI and LI measurements were made between 12:00 and 14:00 $\mathrm{h}$ in full-sun conditions using a $1 \mathrm{~m}$ long SunScan Canopy Analyser (Delta-T Devices Ltd, Cambridge, England). Penetration of photosynthetically active radiation (PAR) below the canopy was measured and a beam fraction sensor on a tripod was used to simultaneously measure incident light above the canopy. LI was calculated as the difference between incident and transmitted light divided by incident light.

Time series data on growth and dry matter production were measured at 33, 51, 65, 83 and 120 DAS in 2004 and at 46, 57, 75, 89 and 124 DAS in 2005. During each sampling, plants from two $1 \mathrm{~m}$ long rows were harvested and separated into leaves, stems and pod components. The components were oven-dried for 2-3 days at $70{ }^{\circ} \mathrm{C}$ before weighing. Total dry weight (TDW) (weight of leaves, stems and pods) and pod harvest index (PHI) (ratio of pod weight to TDW) were computed from individual component dry weights.
Severity of leafspot disease was rated using the Florida scale of 1-10 (Chiteka et al. 1997; 1=no disease or defoliation and $10=$ completely defoliated and killed by leafspot) based on visual observation at 93 and 98 DAS in 2004 and 2005, respectively. At maturity, the middle two rows (each $8 \mathrm{~m}$ long) were harvested to determine pod yield per hectare.

All data were analysed using standard analysis of variance techniques for split-plot experiment in STATISTIX 7 statistical package (Analytical Software, Tallahassee, FL, USA).

\section{RESULTS}

\section{Incidence and severity of leafspot disease}

There were significant $(P<0 \cdot 01)$ effects of fungicide and cultivar treatment on disease scores and proportional defoliation in both years (Fig. 2). The application of fungicide decreased the average leafspot disease scores from 6.8 to 2.2 in 2004 and from 6.5 to 2.4 in 2005 . Averaged across all treatments, the early maturing Chinese cultivar had higher disease scores (5.3 and 5.4 in 2004 and 2005, respectively) compared with the late maturing Manipinter culti$\operatorname{var}(3.8$ and 3.6 in 2004 and 2005, respectively). Accordingly, the early maturing Chinese cultivar had greater leaf defoliation $(0.43$ and 0.42 in 2004 and 


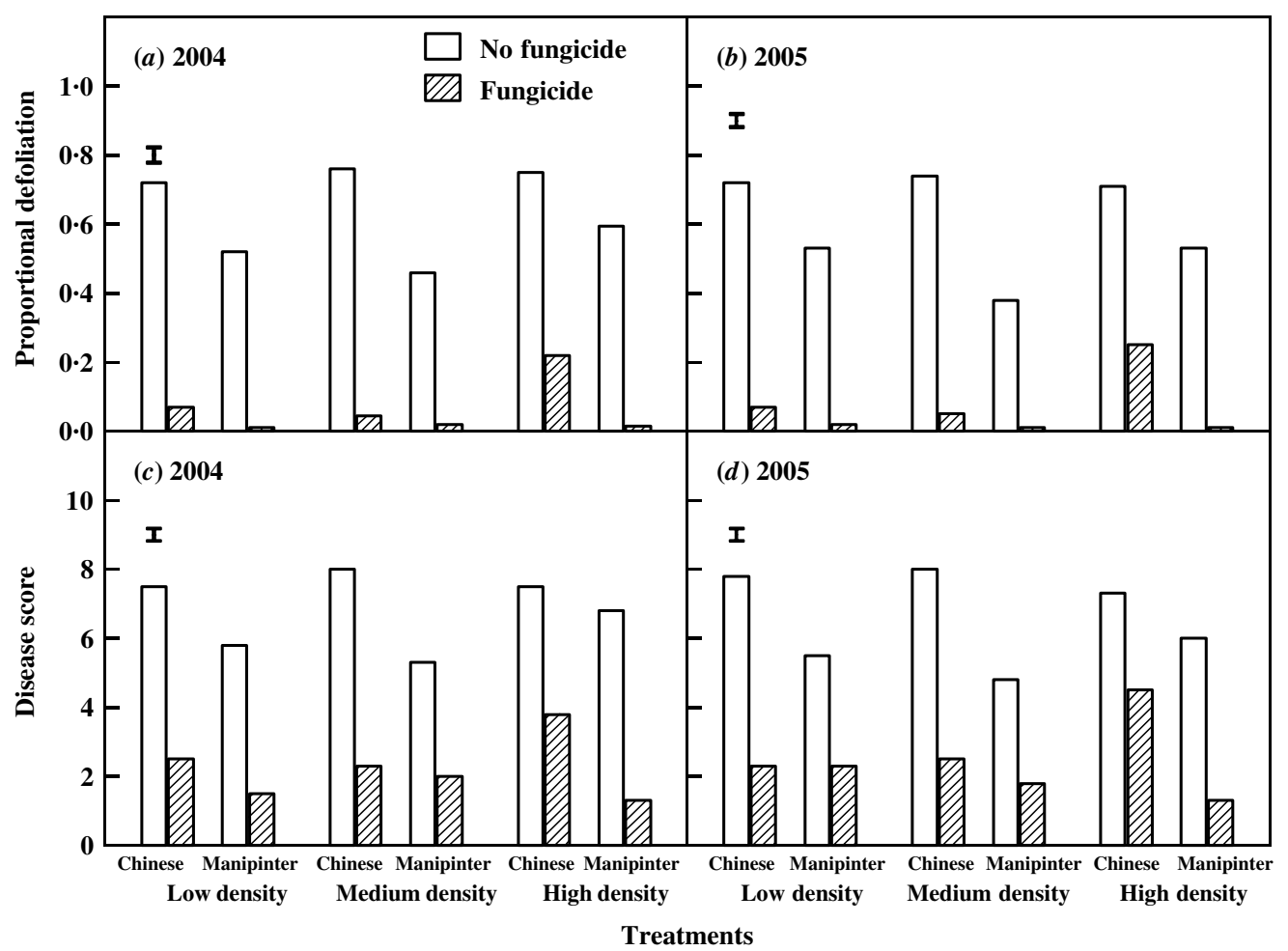

Fig. 2. Influence of fungicide, cultivars and sowing densities on proportional main stem defoliation $(a$ and $b)$ and disease scores $(c$ and $d$ ) in 2004 and 2005 . Vertical bars denote the S.E.D. values.

2005 , respectively) compared with the late maturing Manipinter cultivar $(0 \cdot 27$ and $0 \cdot 24$, respectively). There was no influence of sowing density on visual disease scores.

There were no interactions between fungicide and cultivar, fungicide and sowing density, and cultivar and sowing density on either disease scores or proportional defoliation in both years. The higher order interaction between fungicide, cultivar and density was significant $(P<0.05)$ for both disease scores and defoliation in both years (Fig. 2). Application of fungicide on the early maturing cultivar Chinese at the highest density was not as effective when compared with all other treatments, thus resulting in higher disease scores and defoliation (Fig. 2).

\section{$L A I$}

LAI was increased by fungicide application at 65 and 77 DAS in 2004 and at 83 and 90 DAS in 2005 (Table 1). In 2004, there were no significant differences between cultivars on LAI except at 41 and 88 DAS. At 41 DAS, the early maturing cultivar Chinese had higher LAI (1.4) than the late maturing cultivar Manipinter (1.0). In contrast, at 88 DAS cultivar Manipinter had a higher LAI (3.4) than cultivar Chinese. In 2005, cultivar Manipinter had higher LAI than the early maturing cultivar Chinese on all days of measurements after 63 DAS.

LAI was significantly influenced by sowing density on all dates of measurement except at 88 DAS in 2004. At 58, 65 and 77 DAS, LAI at medium and high sowing densities was greater than that at the lowest density. In 2005, LAI was higher at high sowing density than at the low sowing densities only at 63 DAS. Overall, there were no significant differences in medium and high sowing density.

There was an interaction $(P<0 \cdot 05)$ between fungicide by cultivar on LAI at 77 and 88 DAS in 2004, and at 98 DAS in 2005 (Fig. 3). Fungicide application significantly increased LAI of both cultivars in 2005 and in cultivar Chinese in 2004. However, without fungicide, the LAI of cultivar Chinese declined rapidly and was lowest when compared with Manipinter.

\section{$L I$}

Fungicide application significantly increased LI when compared with no fungicide application in cultivar Chinese at 77 and 88 DAS in 2004 and at 74, 83 and 98 DAS for both cultivars in 2005 (Table 2; Fig. 4). However, the effect of fungicide on LI was lower in 
Table 1. Main effects of fungicide, cultivar and sowing density on LAI of groundnut during 2004 and 2005

\begin{tabular}{|c|c|c|c|c|c|c|c|c|c|}
\hline \multirow{3}{*}{ Treatment } & \multicolumn{5}{|c|}{2004} & \multicolumn{4}{|c|}{2005} \\
\hline & \multicolumn{5}{|c|}{ DAS } & \multicolumn{4}{|c|}{ DAS } \\
\hline & 41 & 58 & 65 & 77 & 88 & 63 & 74 & 83 & 90 \\
\hline \multicolumn{10}{|l|}{ Fungicide (F) } \\
\hline No fungicide & $1 \cdot 2$ & $2 \cdot 0$ & $2 \cdot 0$ & $2 \cdot 8$ & $2 \cdot 7$ & $1 \cdot 8$ & 1.9 & $2 \cdot 1$ & $1 \cdot 6$ \\
\hline Fungicide & $1 \cdot 2$ & $2 \cdot 2$ & $2 \cdot 5$ & $3 \cdot 6$ & $3 \cdot 2$ & $2 \cdot 0$ & $2 \cdot 6$ & $3 \cdot 1$ & $2 \cdot 6$ \\
\hline S.E.D. $($ D.F. $=3)$ & NS & NS & $0 \cdot 1$ & $0 \cdot 2$ & NS & NS & NS & $0 \cdot 1$ & $0 \cdot 1$ \\
\hline \multicolumn{10}{|l|}{ Cultivars (C) } \\
\hline Chinese & $1 \cdot 4$ & $2 \cdot 2$ & $2 \cdot 3$ & $3 \cdot 1$ & $2 \cdot 5$ & 1.9 & $2 \cdot 0$ & $2 \cdot 2$ & 1.9 \\
\hline Manipinter & $1 \cdot 0$ & $2 \cdot 0$ & $2 \cdot 2$ & $3 \cdot 3$ & $3 \cdot 4$ & 1.9 & $2 \cdot 5$ & $2 \cdot 9$ & $2 \cdot 3$ \\
\hline S.E.D. $($ D.F. $=6)$ & $0 \cdot 05$ & NS & NS & NS & $0 \cdot 1$ & NS & $0 \cdot 1$ & $0 \cdot 2$ & $0 \cdot 1$ \\
\hline \multicolumn{10}{|l|}{ Sowing density (D) } \\
\hline Low & $1 \cdot 0$ & $1 \cdot 8$ & $2 \cdot 0$ & $3 \cdot 0$ & $2 \cdot 9$ & $1 \cdot 7$ & $2 \cdot 1$ & $2 \cdot 4$ & $2 \cdot 0$ \\
\hline Medium & $1 \cdot 2$ & $2 \cdot 1$ & $2 \cdot 2$ & $3 \cdot 2$ & $2 \cdot 9$ & $1 \cdot 8$ & $2 \cdot 4$ & $2 \cdot 6$ & $2 \cdot 1$ \\
\hline High & $1 \cdot 4$ & $2 \cdot 5$ & $2 \cdot 6$ & $3 \cdot 0$ & $3 \cdot 0$ & $2 \cdot 2$ & $2 \cdot 4$ & $2 \cdot 7$ & $2 \cdot 1$ \\
\hline S.E.D. (D.F. $=24)$ & $0 \cdot 1$ & $0 \cdot 2$ & $0 \cdot 2$ & $0 \cdot 1$ & NS & $0 \cdot 2$ & NS & NS & NS \\
\hline
\end{tabular}

NS $=$ not significant $P>0 \cdot 05$.

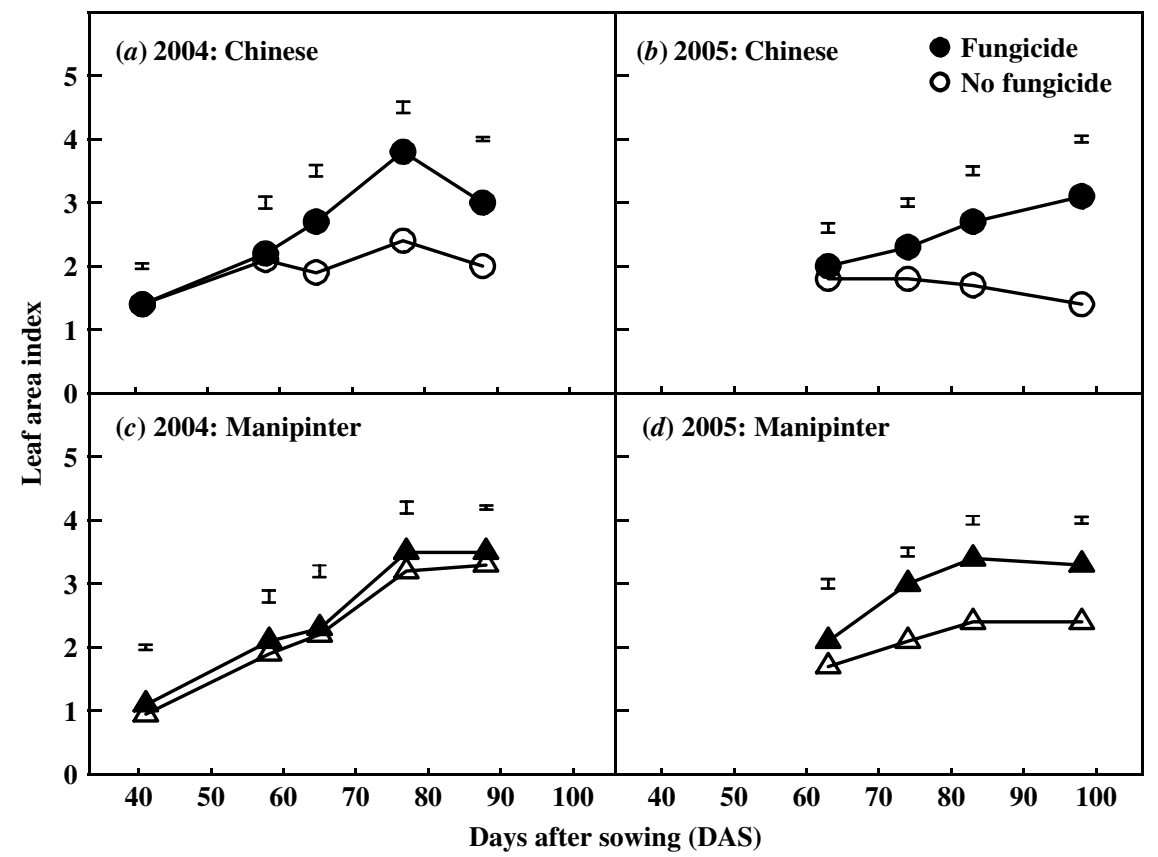

Fig. 3. Influence of fungicide on LAI over time for cultivar Chinese ( $a$ and $b)$ and cultivar Manipinter $(c$ and $d)$ in 2004 and 2005. Vertical bars denote the S.E.D. values.

cultivar Manipinter compared with cultivar Chinese at 83 and 98 DAS. Overall, long-duration cultivar Manipinter had significantly higher LI than the early maturing cultivar Chinese during later stages of crop development (88 DAS in 2004 and at 74, 83 and 98
DAS in 2005). There were significant differences between sowing densities in LI at 77 DAS in 2004 and at 63, 74 and 98 DAS in 2005, where LI was significantly smaller in lower sowing density when compared with medium or high sowing density. 
Table 2. Main effects of fungicide, cultivar and sowing density on the proportion of light intercepted by groundnut during 2004 and 2005

\begin{tabular}{|c|c|c|c|c|c|c|c|}
\hline \multirow{3}{*}{ Treatment } & \multicolumn{3}{|c|}{2004} & \multicolumn{4}{|c|}{2005} \\
\hline & \multicolumn{3}{|c|}{ DAS } & \multicolumn{4}{|c|}{ DAS } \\
\hline & 65 & 77 & 88 & 63 & 74 & 83 & 90 \\
\hline \multicolumn{8}{|l|}{ Fungicide (F) } \\
\hline No fungicide & $0 \cdot 73$ & $0 \cdot 83$ & $0 \cdot 80$ & $0 \cdot 70$ & 0.74 & 0.75 & $0 \cdot 66$ \\
\hline Fungicide & $0 \cdot 78$ & $0 \cdot 89$ & $0 \cdot 86$ & 0.75 & $0 \cdot 82$ & $0 \cdot 85$ & $0 \cdot 82$ \\
\hline S.E.D. (D.F. = 3) & NS & 0.01 & NS & NS & 0.04 & 0.03 & $0 \cdot 05$ \\
\hline \multicolumn{8}{|l|}{ Cultivars (C) } \\
\hline Chinese & $0 \cdot 77$ & $0 \cdot 85$ & 0.79 & 0.72 & 0.75 & 0.76 & 0.69 \\
\hline Manipinter & 0.74 & $0 \cdot 88$ & $0 \cdot 88$ & 0.73 & $0 \cdot 81$ & $0 \cdot 84$ & $0 \cdot 78$ \\
\hline S.E.D. (D.F. $=6)$ & NS & NS & 0.03 & NS & $0 \cdot 02$ & $0 \cdot 01$ & $0 \cdot 02$ \\
\hline \multicolumn{8}{|l|}{ Sowing density (D) } \\
\hline Low & 0.73 & $0 \cdot 85$ & $0 \cdot 83$ & $0 \cdot 70$ & 0.75 & 0.79 & $0 \cdot 72$ \\
\hline Medium & 0.75 & $0 \cdot 86$ & 0.83 & 0.71 & $0 \cdot 79$ & $0 \cdot 81$ & $0 \cdot 75$ \\
\hline High & $0 \cdot 78$ & $0 \cdot 88$ & $0 \cdot 84$ & $0 \cdot 77$ & $0 \cdot 79$ & $0 \cdot 81$ & $0 \cdot 74$ \\
\hline S.E.D. (D.F. $=24)$ & NS & $0 \cdot 01$ & NS & 0.02 & $0 \cdot 01$ & NS & NS \\
\hline
\end{tabular}

$\mathrm{NS}=$ not significant $P>0 \cdot 05$.

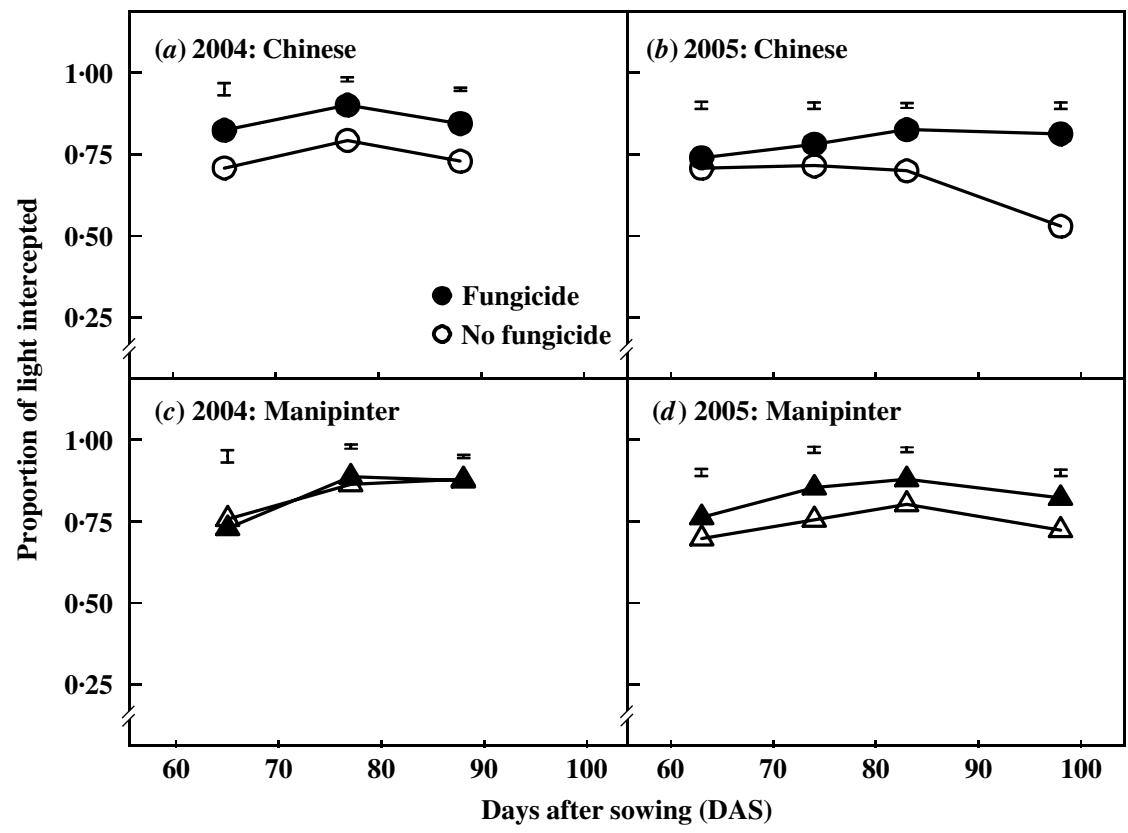

Fig. 4. Influence of fungicide on proportion of LI overtime for cultivar Chinese $(a$ and $b)$ and cultivar Manipinter $(c$ and $d)$ in 2004 and 2005. Vertical bars denote the S.E.D. values.

The interaction between fungicide and cultivar was significant at $77(P<0.05)$ and $88(P<0.01)$ DAS in 2004 and at 98 DAS $(P<0 \cdot 05)$ in 2005 (Fig. 4). In 2005 only, for both cultivars, LI was higher with fungicide application than without fungicide application. With fungicide application, the late maturing cultivar Manipinter had similar LI as that of early maturing Chinese cultivar. However, without fungicide application, cultivar Chinese had significantly lower LI than Manipinter. 
Table 3. Main effects of fungicide, cultivar and sowing density on TDWs $(\mathrm{kg} / \mathrm{ha})$ of groundnut during 2004 and 2005

\begin{tabular}{|c|c|c|c|c|c|c|c|c|c|c|}
\hline \multirow{3}{*}{ Treatment } & \multicolumn{5}{|c|}{2004} & \multicolumn{5}{|c|}{2005} \\
\hline & \multicolumn{5}{|c|}{ DAS } & \multicolumn{5}{|c|}{ DAS } \\
\hline & 33 & 51 & 65 & 83 & 120 & 46 & 57 & 75 & 89 & 124 \\
\hline \multicolumn{11}{|l|}{ Fungicide (F) } \\
\hline No fungicide & 429 & 1019 & 1806 & 2612 & 2685 & 752 & 1769 & 3708 & 3292 & 2706 \\
\hline Fungicide & 444 & 1087 & 2645 & 3964 & 4777 & 975 & 2070 & 5554 & 6082 & 6407 \\
\hline S.E.D. (D.F. = 3) & NS & NS & 185 & 201 & 387 & NS & NS & NS & 688 & 1034 \\
\hline \multicolumn{11}{|l|}{ Cultivars (C) } \\
\hline Chinese & 482 & 1095 & 2181 & 2776 & 2791 & 860 & 1836 & 3816 & 3756 & 3476 \\
\hline Manipinter & 391 & 1010 & 2270 & 3800 & 4672 & 867 & 2003 & 5445 & 5619 & 5636 \\
\hline S.E.D. $($ D.F. $=6)$ & 35 & NS & NS & 255 & 332 & NS & NS & 779 & 394 & 177 \\
\hline \multicolumn{11}{|l|}{ Sowing density (D) } \\
\hline Low & 380 & 842 & 1958 & 3072 & 3381 & 706 & 1535 & 4818 & 4648 & 4126 \\
\hline Medium & 447 & 1007 & 2191 & 3446 & 3756 & 874 & 2035 & 4108 & 4622 & 4470 \\
\hline High & 482 & 1310 & 2526 & 3346 & 4057 & 1010 & 2188 & 4967 & 4792 & 5073 \\
\hline S.E.D. (D.F. $=24)$ & 30 & 120 & 200 & NS & 146 & 91 & 166 & NS & NS & 293 \\
\hline
\end{tabular}

NS $=$ not significant $P>0 \cdot 05$.

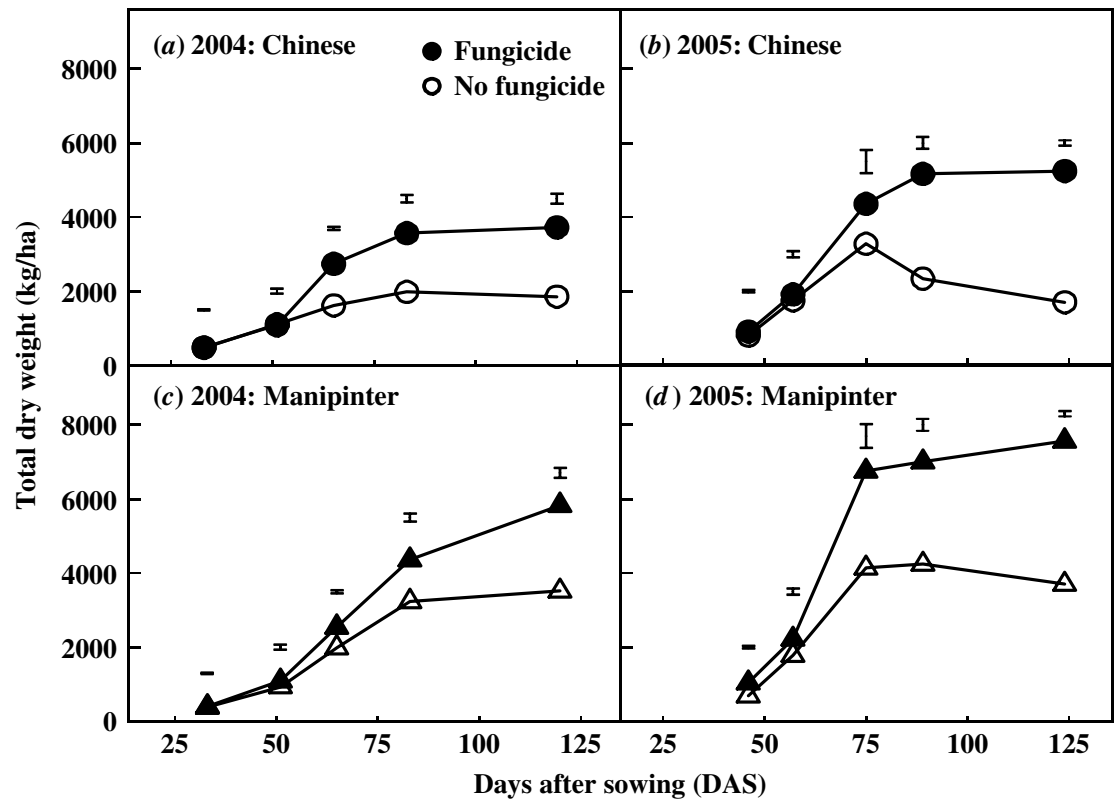

Fig. 5. Influence of fungicide on TDW accumulation over time for cultivar Chinese $(a$ and $b)$ and cultivar Manipinter $(c$ and $d$ ) in 2004 and 2005. Vertical bars denote the S.E.D. values.

$T D W$

Overall, fungicide application significantly increased TDWs by 46,52 and $78 \%$ at 65,83 and 120 DAS, respectively, in 2004 (Table 3). Similarly, fungicide application enhanced TDW by 84 and $136 \%$ at 89 and 124 DAS in 2005. As expected, fungicide effects on total dry matter became progressively larger later in the season, consistent with progressive disease effects on unsprayed treatments (Table 3; Fig. 5). 
Table 4. Main effects of fungicide, cultivar and sowing density on haulm, pod, seed yields, TDW accumulation (all in $\mathrm{kg} / \mathrm{ha}$ ) and PHI of groundnut at harvest maturity in 2004 and 2005

\begin{tabular}{lccccc}
\hline \hline Treatments & $\begin{array}{c}\text { Haulm yield } \\
(\mathrm{kg} / \mathrm{ha})\end{array}$ & $\begin{array}{c}\text { Pod yield } \\
(\mathrm{kg} / \mathrm{ha})\end{array}$ & $\begin{array}{c}\text { Seed yield } \\
(\mathrm{kg} / \mathrm{ha})\end{array}$ & $\begin{array}{c}\text { TDW } \\
(\mathrm{kg} / \mathrm{ha})\end{array}$ & PHI \\
\hline 2004 & & & & & \\
Fungicide (F) & & & & & \\
No fungicide & 1732 & 953 & 583 & 2685 & $0 \cdot 38$ \\
Fungicide & 2993 & 1784 & 1272 & 4777 & $0 \cdot 39$ \\
S.E.D. (D.F.=3) & 322 & 125 & 67 & 388 & NS \\
Cultivar (C) & & & & & \\
Chinese & 1553 & 1238 & 843 & 2791 & $0 \cdot 45$ \\
Manipinter & 3172 & 1500 & 1012 & 4672 & $0 \cdot 32$ \\
S.E.D. (D.F.=6) & 228 & 147 & 65 & 333 & $0 \cdot 03$ \\
Sowing density (D) & & & & & \\
Low & 2149 & 1231 & 845 & 3381 & $0 \cdot 39$ \\
Medium & 2389 & 1367 & 892 & 3756 & $0 \cdot 38$ \\
High & 2549 & 1508 & 1045 & 4057 & $0 \cdot 38$ \\
S.E.D. (D.F.=24) & 109 & 88 & 80 & 146 & NS \\
2005 & & & & & \\
Fungicide (F) & & & & & \\
No fungicide & 1562 & 1104 & 797 & 2706 & $0 \cdot 47$ \\
Fungicide & 4183 & 2224 & 1500 & 6407 & $0 \cdot 36$ \\
S.E.D. (D.F.=3) & 870 & 183 & 64 & 1035 & NS \\
Cultivar (C) & & & & \\
Chinese & 1957 & 1479 & 1052 & 3476 & $0 \cdot 48$ \\
Manipinter & 3787 & 1849 & 1245 & 5636 & $0 \cdot 35$ \\
S.E.D. (D.F.=6) & 96 & 147 & 64 & 177 & $0 \cdot 05$ \\
Sowing density (D) & & & & & \\
Low & 2618 & 1507 & 1016 & 4126 & $0 \cdot 42$ \\
Medium & 2837 & 1633 & 1141 & 4470 & $0 \cdot 42$ \\
High & 3161 & 1852 & 1289 & 5073 & $0 \cdot 40$ \\
S.E.D. (D.F.=24) & NS & 99 & 79 & 293 & NS \\
\hline \hline
\end{tabular}

NS $=$ not significant $P>0 \cdot 05$.

The main effects of cultivar on TDW were increasingly evident after 60-70 DAS. Long-duration cultivar Manipinter produced greater TDW at 83 and 120 DAS, in 2004, and at 75, 89 and 124 DAS in 2005, when compared with short-duration cultivar Chinese.

In 2004, TDW was significantly greater at high sowing density than at low sowing density at 33,51 , 65 and 120 DAS and also higher than that at medium sowing density at 51 and 120 DAS (Table 3). In 2005, TDW was higher at high sowing density compared with low sowing density at 46, 57 and 124 DAS, while TDW at medium density was higher than that at low density only at 57 DAS. There were no significant effects of interactions between the treatments across all sampling dates.

\section{Yield}

There were significant effects of fungicide and sowing density on haulm, pod and seed yields and TDW at maturity in both years (Table 4; Fig. 6). Fungicide treatment almost doubled haulm, pod, seed yield and total dry matter accumulation when compared with unsprayed control ( $-\mathrm{F}$ treatment). The effects of cultivar were significantly different in both years. Long-duration cultivar Manipinter produced significantly greater haulm, pod, seed yield and total dry matter than the short-duration cultivar Chinese. Haulm, pod and seed yield and total dry matter were less at low sowing density when compared with medium or high sowing density (Table 4). However, there were no differences between medium and high sowing density in haulm, pod and seed yield and total dry matter at maturity.

There were no interactions between fungicide application, cultivar and sowing densities on haulm, pod, seed or TDWs in both years. The interaction between fungicide and cultivar was significant $(P<$ $0 \cdot 05$ ) for haulm yield only. In 2005 , there was significant interaction $(P<0.05)$ between fungicide and sowing density on pod yield (Fig. 6). With fungicide application, the medium and high sowing densities 


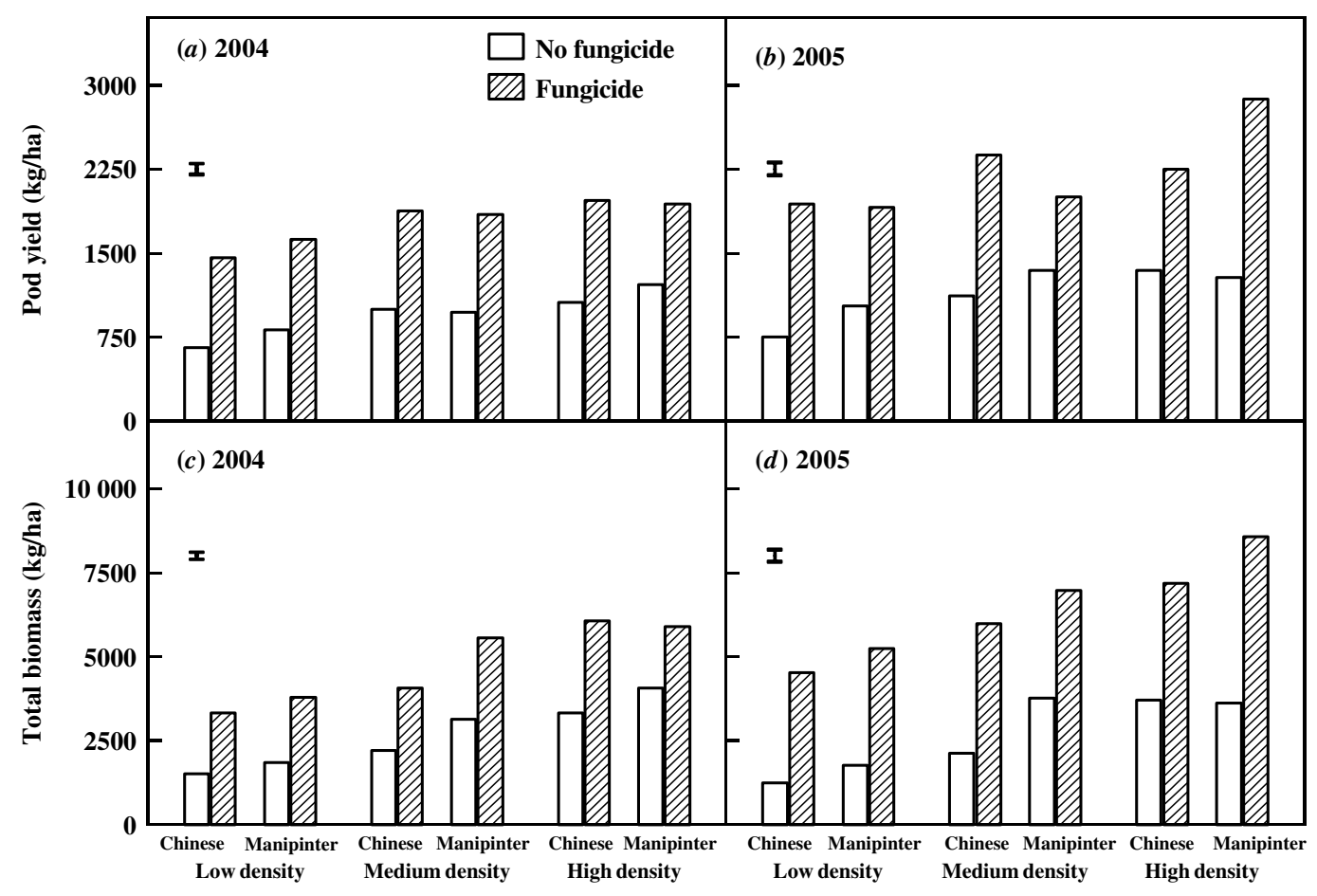

Treatments

Fig. 6. Influence of fungicide, cultivars and sowing densities on pod yield ( $a$ and $b$ ) and TDWs ( $c$ and $d$ ) in 2004 and 2005. Vertical bars denote the s.E.D. values.

increased pod yield by 8 and $13 \%$ in 2004 and by 5 and $25 \%$ in 2005 compared with low sowing density. Without fungicide, the medium and high density increased pod yield by 13 and $31 \%$, respectively, over low density in 2004 and by 12 and $13 \%$, respectively, in 2005 .

\section{PHI}

PHI significantly increased in 2005 , from 0.36 in the non-sprayed control to 0.47 in the crops treated with fungicide, while there were no effects in 2004 (Table 4). Overall, the short-duration cultivar Chinese had higher PHI (0.45 and 0.48 in 2004 and 2005, respectively) when compared with long-duration cultivar Manipinter $(0.32$ and 0.35 , in 2004 and 2005, respectively). There was no influence of sowing densities or interaction between various treatments on PHI, with an exception of cultivar by density interaction $(P<0.05)$ and between fungicide by cultivar by density interaction $(P<0.05)$ in 2005 . The cultivar by density interactions suggests that there was no effect of sowing density in long-duration cultivar Manipinter, whereas in short-duration cultivar Chinese the highest population density resulted in significantly lower PHI (0.46) when compared with medium (0.49) or low $(0.52)$ sowing densities.

\section{DISCUSSION}

There was severe occurrence of leafspot disease in both years as evident by disease scores based on the visual symptoms. Typical symptoms of both early and late leafspot disease, as described by Subrahmanyam et al. (1992), appeared at 25-28 DAS in non-sprayed plots. Early leafspots are brown to reddish in colour and always have a yellow halo; they mostly form on the upper surface of the leaf, giving it a slightly raised surface (Subrahmanyam et al. 1992; Nutter \& Shokes 1995). Late leafspots are dark brown to black in colour, do not have a yellow halo and mostly form on the lower surface of the leaves, giving it a rough and tufted appearance (Subrahmanyam et al. 1992; Nutter \& Shokes 1995). On average, the severity of disease with no fungicide was slightly higher in 2004 (disease score of 6.8 and proportional defoliation of 0.63 ) compared with 2005 (disease score of 6.5 and proportional defoliation $0 \cdot 60$ ). This was attributed to wet weather; more rain in 2004 (Fig. 1) may have resulted in prolonged 


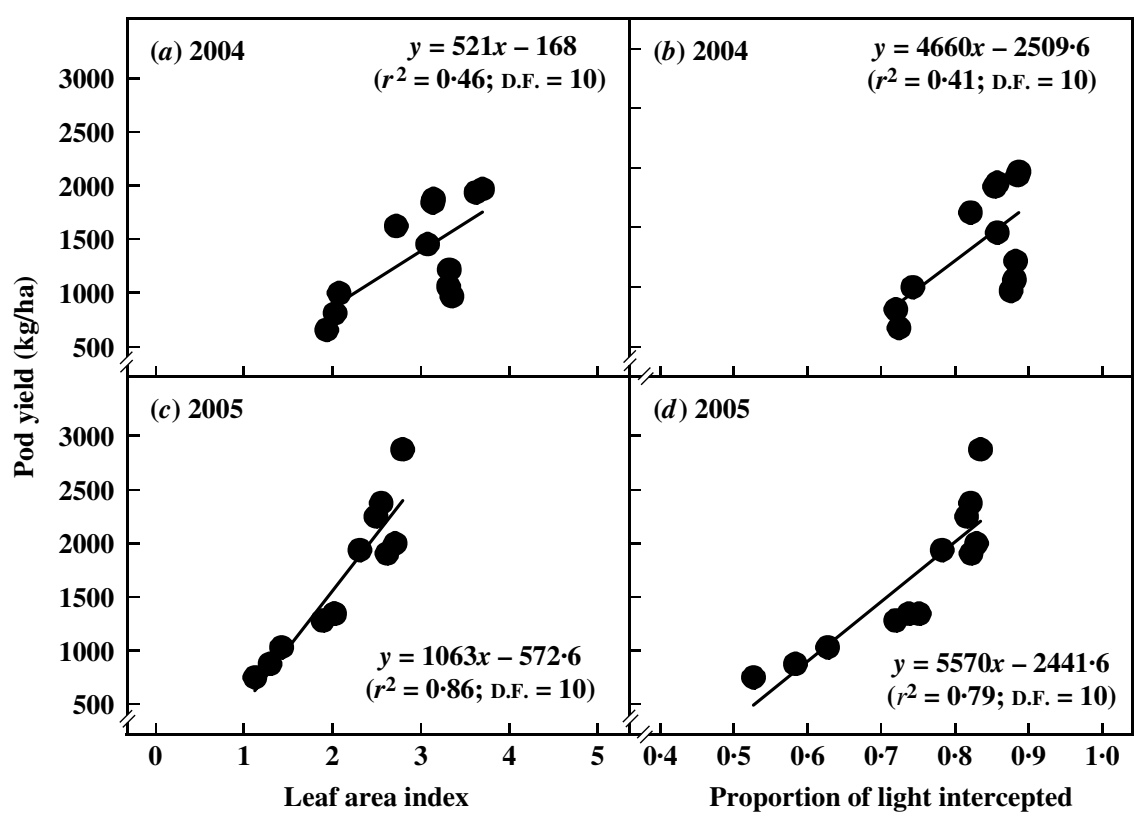

Fig. 7. Relations between pod yield at maturity and LAI ( $a$ and $c$ ), and proportion of LI ( $b$ and $d$ ) measured at 88 DAS in 2004 and at 120 DAS in 2005.

periods of humidity and leaf wetness, which results in greater disease (Smith et al. 1992; Butler et al. 1994; Nutter \& Shokes 1995).

Fungicide was effective in controlling leafspot disease, as shown by the low disease scores $(2 \cdot 3)$ and proportional defoliation $(0 \cdot 7)$ when compared with non-sprayed plots (Fig. 2). Overall in the present study, application of fungicide significantly increased LAI and LI throughout the growing season and increased total dry matter by $107 \%$ and pod yields by $95 \%$ (Table 4 ). In general, the fungicide-induced increases in LAI were greater later in the growing season, associated with reduced defoliation. There were strong positive relations between LI, LAI and pod yield (Fig. 7). Similarly, there were strong negative relations between disease scores, defoliation and pod yield (Fig. 8). This improved knowledge can be used for developing or improving existing disease models. However, the decline in yield was more rapid (steeper) than the loss of leaf area and LI, implying also leafspot-induced reduction in photosynthetic effectiveness of remaining foliage. This suggests the need to understand the precise mechanisms of photosynthetic effectiveness as affected by disease and also the mechanisms by which fungicide maintains green leaf area duration and its effectiveness. Previous research has shown that the reduction in pod yield due to the occurrence of leafspot is mainly attributed to leaf loss and reduced LAI due to defoliation (Boote et al. 1980; Subrahmanyam et al. 1992; Adomou et al.
2005), which decreases LI by crop canopies. The effect of necrotic spots on the photosynthesis of remaining leaves may be an important mechanism of a minor additional component of yield loss (Pixley et al. 1990 a ; Bourgeois \& Boote 1992; Adomou et al. 2005). The severe decrease in yields in 2004, despite only moderately decreased LAI and LI, suggests that decreased photosynthesis of remaining leaves is an important mechanism. However, an additional consideration is that the instrumentation used for measuring LI in the present study would also perceive stems and petioles and dead leaves as LAI, thus minimizing the measured effects of green LAI loss. The yield responses to fungicide application in the present study are similar to those obtained in previous research (Naab et al. 2005) and similar to that of other researchers in Africa and elsewhere (Smith \& Littrell 1980; Kanniyan \& Haciwa 1990; ICRISAT 1991; Waliyar et al. 2000).

There were differences in disease scores, mainstem defoliation, growth and dry matter production of cultivars under both fungicide-sprayed and nonsprayed environments (Figs 2 and 6). Averaging across all treatments, the late maturing cultivar Manipinter produced significantly more total dry matter and pod yields compared with the early maturing cultivar Chinese. The present data show that the longduration cultivar yielded better under both disease and disease-free environments, but especially under disease conditions. This is also evident in disease 


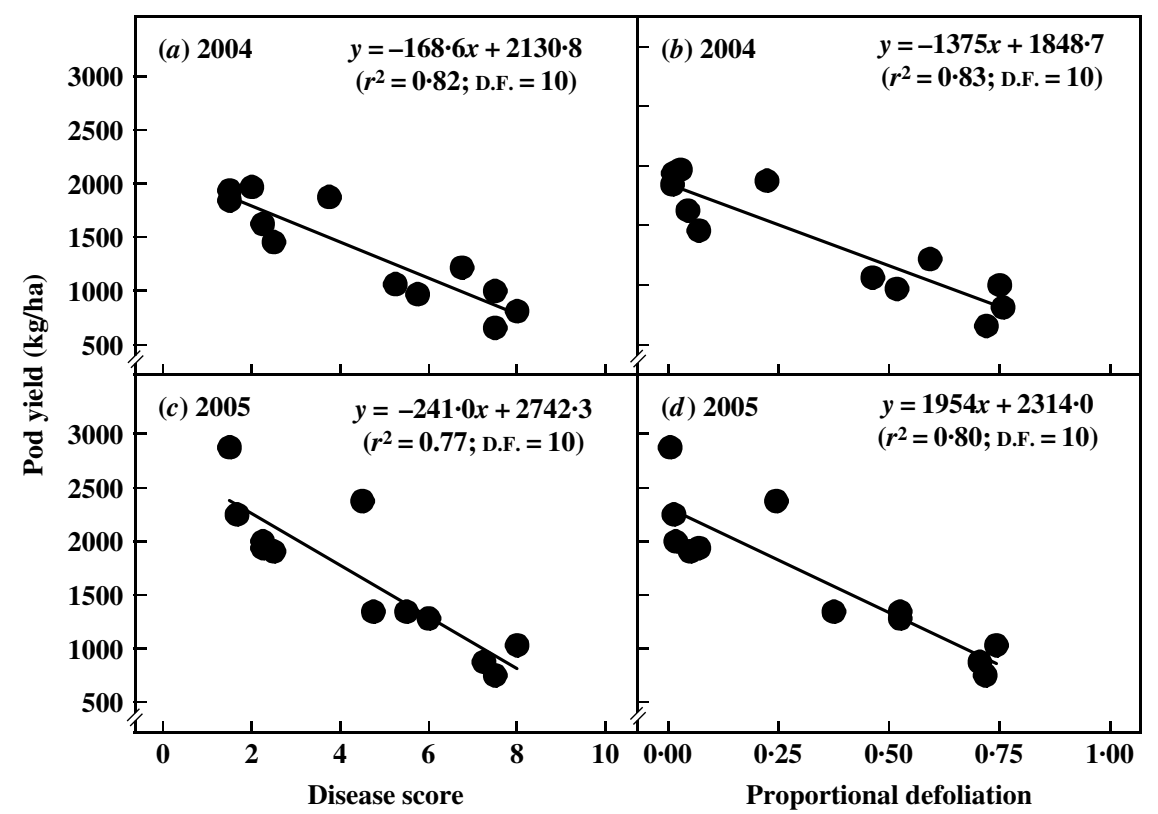

Fig. 8. Relations between pod yield and disease score at maturity ( $a$ and $c$ ) and proportional main stem defoliation at maturity $(b$ and $d)$ in 2004 and 2005.

scores and defoliation data - which show that, without fungicide, cultivar Manipinter has relatively less disease and defoliation across all densities (Fig. 3). However, there is no evidence of true resistance in this cultivar, as the disease was severe in places (disease scores $>5$ ). The greater yields obtained by the long-duration cultivar may be due to longer growing season and relatively prolonged leaf area production, which give it a type of 'tolerance' to leaf spot disease by leaf replacement, as Pixley et al. $(1990 b)$ reported. Since groundnut is an indeterminate crop, a longer growing season or extended leaf production sometimes compensate for yield losses caused by biotic and abiotic stresses. Recent research has also shown evidence of true resistance to leaf spot disease (Subrahmanyam et al. 1982; Pixley et al. $1990 a, b$; Dwivedi et al. 2002; Stalker et al. 2002; Singh et al. 2003). Research is presently under way to identify and/or develop cultivars that can produce greater yields in regions having high leafspot disease pressure.

The present data show that disease scores and main-stem defoliation in the short-duration cultivar Chinese were significantly greater than those of the long-duration cultivar Manipinter even in fungicidetreated plots. This could be attributed to the upright Spanish habit of cultivar Chinese which could result in lower penetration of fungicide, thus resulting in more disease even under sprayed conditions. In contrast, the prostrate nature of Manipinter (Virginia type) may have resulted in better canopy coverage under the same spraying conditions.

The lowest dry matter production and yields were observed in lowest sowing density $\left(8\right.$ plants $\left./ \mathrm{m}^{2}\right)$ when compared with medium (12 plants $\left./ \mathrm{m}^{2}\right)$ and high (20 plants $/ \mathrm{m}^{2}$ ) sowing densities (Tables 3 and 4). There were no differences between the medium and high densities for most traits, particularly under fungicide-sprayed conditions, suggesting that medium density may be optimal for obtaining high pod yields (Fig. 6). Sowing at the medium density increased pod yields by 10 and $8 \%$ when compared with the low sowing density, in 2004 and 2005, respectively. The longer-duration cultivar Manipinter planted at high density with fungicide application resulted in the highest pod yield (Fig. 6). However, with no fungicide, medium-sowing density of the long-duration cultivar Manipinter resulted in higher yields than the short-duration cultivar at the same density (Fig. 6). This suggests that, in general, longerduration cultivars produce higher yields. This research provides new knowledge not only on the importance of fungicide application, cultivar selection and sowing density on peanut disease progress and peanut yield, but also on the need for integrating these effects.

In conclusion, the present research suggests that fungicide application increased pod yield by $95 \%$, and the long-duration cultivar Manipinter had 23\% higher pod yield than cultivar Chinese. Sowing 
densities of 20 v. 12 v. 8 plants $/ \mathrm{m}^{2}$ gave an additional 12 and $23 \%$ pod yield increase in these trials. However, because the quality of seeds available to farmers is often poor, a sowing density higher than the 5-8 plants $/ \mathrm{m}^{2}$ typical of farmer fields may be warranted.
This research was supported by the USAID Peanut Collaborative Research Support Project. We thank Messrs Ibrahim Sunday, Vincent Kunlen, George Mahama and the field staff for technical support. Contribution number 09-043-J from Kansas Agricultural Experiment Station.

\section{REFERENCES}

Adomou, M., Prasad, P. V. V., Boote, K. J. \& Detongnon, J. (2005). Disease assessment methods and their use in simulating growth and yield of peanut crops affected by leafspot disease. Annals of Applied Biology 146, 469-479.

Banterng, P., Patanothai, A., Pannangpetch, K., Jogloy, S. \& Hoogenboom, G. (2003). Seasonal variation in the dynamic growth and development traits of peanut lines. Journal of Agricultural Science, Cambridge 141, 51-62.

Bell, M. J., Harch, G. \& Wright, G. C. (1991). Plant population studies in peanut (Arachis hypogaea L.) in subtropical Australia. 1. Growth under fully irrigated conditions. Australian Journal of Experimental Agriculture 31, 535-543.

Board, J. E. \& Harville, B. G. (1992). Explanations for greater light interception in narrow- vs. wide-row soybean. Crop Science 32, 198-203.

Boote, K. J., Jones, J. W., Smerage, G. H., Barfield, C. S. \& Berger, R. D. (1980). Photosynthesis of peanut canopies as affected by leafspot and artificial defoliation. Agronomy Journal 72, 247-252.

Bourgeois, G. \& Boote, K. J. (1992). Leaflet and canopy photosynthesis of peanut affected by late leaf spot. Agronomy Journal 84, 359-366.

Butler, D. R., Wadia, K. D. R. \& Jadhav, D. R. (1994). Effects of leaf wetness and temperature on late leaf spot infection of groundnut. Plant Pathology 43, 112-120.

Chin-Choy, E. W., Stone, J. F., Stone, R. S., Matlock, R. S. \& McCauley, G. N. (1982). Plant population and irrigation effects on Spanish peanuts (Arachis hypogaea L.). Peanut Science 9, 73-76.

Chiteka, Z. A., Gorbet, D. W., Shokes, F. M. \& Kucharek, T. A. (1997). Components of resistance to early leaf spot in peanut - genetic variability and heritability. Soil and Crop Science Society of Florida Proceedings 56, 63-68.

Cox, F. R. \& Reid, P. H. (1965). Interaction of plant population factors and level of production on the yield and grade of peanuts. Agronomy Journal 57, 455-457.

Dimmock, J. P. R. E. \& Gooding, M. J. (2002). The influence of foliar diseases, and their control by fungicides, on the protein concentration in wheat grain: a review. Journal of Agricultural Science, Cambridge 138, 349-366.

Dwivedi, S. L., Pande, S., Rao, J. N. \& Nigam, S. N. (2002). Components of resistance to late leafspot and rust among interspecific derivatives and their significance in a foliar disease resistance breeding in groundnut (Arachis hypogaea L.). Euphytica 125, 81-88.

FAO (2005). Crop Production Statistics. Rome, Italy: Food and Agricultural Organization of United Nations. http:// faostat.fao.org (verified 9 April 2008).

Farrel, J. K., Bailey, J. E. \& Mills, W. R. (1967). The effects of time of planting, spacing and fungicide on Cercospora leaf spots on groundnut in Malawi, Rhodesia and Zambia. Malawi Journal of Agricultural Research $\mathbf{5}$, 241-247.
ICRISAT (1991). ICRISAT West Africa Program Annual Report 1991. Sahelian Center, Niamey, Niger: ICRISAT.

Kannaiyan, J. \& Haciwa, H. C. (1990). Economic benefits of spraying fungicides to control groundnut foliar disease in Zambia. Tropical Pest Management 36, 21-22.

Kumar, M. A. \& Venkatachari, A. (1971). Studies on the effect of intra-row spacing and fertility levels on the yield and quality of two varieties of groundnut (Arachis hypogaea L.). Indian Journal of Agricultural Research $\mathbf{5}$, 67-79.

Lanier, J. E., Jordon, J. L., Spears, J. F., Wells, R., Johnson, P. D., Barnes, J. S., Hurt, C. A., BrandenburG, R. L. \& Bailey, J. E. (2004). Peanut response to planting pattern, row spacing and irrigation. Agronomy Journal 96, 1066-1072.

MArLey, P. S. (2004). Effects of integrated host plant resistance with time of planting or fungicides on anthracnose and grain mould and yield of sorghum (Sorghum bicolor) in Nigerian northern Guinea Savanna. Journal of Agricultural Science, Cambridge 142, 345-350.

Mayeux, A. \& Maphanyane, G. S. (1989). Groundnut cultivation under low rainfall conditions in Botswana. In Proceedings of Third Regional Groundnut Workshop for Southern Africa, 13-18 March 1988, Lilongwe, Malawi (Eds J. J. Abraham \& K. R. Bock), pp. 149-155. Patancheru, India: ICRISAT.

Mercer-Quarshie, H. (1972). Effect of inter-ridge and within-ridge plant spacing on the performance of groundnut (Arachis hypogaea L.) in North Ghana. Ghana Journal of Agricultural Science 5, 103-109.

Mligo, J. K. \& Craufurd, P. Q. (2007). Productivity and optimum plant density of pigeonpea in different environments in Tanzania. Journal of Agricultural Science, Cambridge 145, 343-351.

Naab, J. B., Tsigbey, F. K., Prasad, P. V. V., Boote, K. J., Bailey, J. E. \& Brandenburg, R. L. (2005). Effects of sowing date and fungicide application on yield of early and late maturing peanut cultivars grown under rainfed conditions in Ghana. Crop Protection 24, 325-332.

Nutter, F. W. \& Shokes, F. M. (1995). Management of foliar diseases caused by fungi. In Peanut Health Management (Eds H. A. Melouk \& F. M. Shokes), pp. 65-73. St. Paul, MN: American Phytopathological Society Press.

Pixley, K. V., Boote, K. J., Shokes, F. M. \& Gorbet, D. W. $(1990 a)$. Disease progression and leaf-area dynamics of four peanut genotypes differing in resistance to late leafspot. Crop Science 30, 789-796.

Pixley, K. V., Boote, K. J., Shokes, F. M. \& Gorbet, D. W. $(1990 \mathrm{~b})$. Growth and partitioning characteristics of four peanut genotypes differing in resistance to late leafspot. Crop Science 30, 796-804.

Roy, R. C., Tanner, J. W., Hatley, O. E. \& Elliot, J. M. (1980). Agronomic aspects of peanut (Arachis hypogaea 
L.) production in Ontario. Canadian Journal of Plant Sciences 60, 679-686.

Russell, P. E. (2005). A century of fungicide evolution. Journal of Agricultural Science, Cambridge 143, 11-25.

Shokes, F. M. \& Culbreath, A. K. (1997). Early and late leaf spots. In Compendium of Peanut Diseases, 2nd edition (Eds N. K. Burelle, D. M. Porter, R. R. Kabana, D. H. Smith \& P. Subrahmanyam), pp. 17-20. St Paul, MN: American Phytopathology Society.

Singh, A. K., Dwivedi, S. L., Pande, S., Moss, J. P., Nigam S. N. \& SASTRI, D. S. (2003). Registration of rust and late leafspot resistant peanut germplasm lines. Crop Science 43, 440-441.

Smith, D. H. \& Littrell, R. H. (1980). Management of peanut foliar diseases with fungicides. Plant Disease 64, 356-361.

Smith, D. H., Pauer, G. D. C. \& Shokes, F. M. (1992). Cercosporidium and cercospora leafspot of peanut (groundnut). In Plant Disease of International Importance, vol. 2 (Eds U. S. Singh, A. N. Mukhopadhyay, J. Kumar \& H. S. Chaube), pp. 285-304. Englewood Cliffs, NJ: Prentice Hall Inc.

Stalker, H. T., Beute, M. K., Shew, B. B. \& Isleib, T. G. (2002). Registration of five leafspot resistant peanut germplasm. Crop Science 42, 314-316.
Subrahmanyam, P., McDonald, D., Gibbons, R. W., Nigam, S. N. \& Nevill, D. J. (1982). Resistance to rust and late leaf spot diseases in some genotypes of Arachis hypogaea L. Peanut Science 9, 6-10.

Subrahmanyam, P., Wongkaew, S., Reddy, D. V. R., Demski, J. W., McDonald, D., Sharma, S. B. \& Smith, D. H. (1992). Field Diagnosis of Groundnut Diseases. Information Bulletin No. 36. Patancheru, Andhra Pradesh, India: ICRISAT.

Waliyar, F. (1991). Evaluation of yield losses due to groundnut leaf diseases in West Africa. In Summary Proceedings of the Second ICRISAT Regional Groundnut Meeting for West Africa, 11-14 September 1990, Niamey, Niger (Eds B. J. Nduguru, F. Waliar \& B. R. Ntare), pp. 32-33. Patancheru, India: ICRISAT.

Waliyar, F., Adomou, M. \& Traore, A. (2000). Rational use of fungicide applications to maximize peanut yield under foliar disease pressure in West Africa. Plant Disease 84, 1203-1211.

Wright, G. C. \& Bell, M. J. (1992). Plant population studies on peanut (Arachis hypogaea L.) in subtropical Australia. 3. Growth and water use during terminal drought stress. Australian Journal of Experimental Agriculture 32, 197-203. 